\title{
Procrastination in the early detection of breast cancer
}

\author{
Procrastinação na deteç̧ão precoce do câncer de mama \\ Procrastinación en la detección precoce del cáncer de mama
}

\section{Cleoneide Paulo Oliveira Pinheiro' ORCID: 0000-0003-1784-7446}

Raimunda Magalhães da Silva" ORCID: 0000-0001-5353-7520

Christina César Praça Brasil" ORCID: 0000-0002-7741-5349

Indara Cavalcante Bezerra" ORCID: 0000-0003-0647-2490

Ana Nery Melo Cavalcante" ORCID: 0000-0002-3830-7767

Aimêe Veras Alexandre" ORCID: 0000-0002-3949-6483

Cleciana Alves Cruz" ORCID: 0000-0002-9443-4955

'Centro Universitário Estácio de Sá. Fortaleza, Ceará, Brazil. "Universidade de Fortaleza. Fortaleza, Ceará, Brazil.

How to cite this article: Pinheiro CPO, Silva RM, Brasil CCP, Bezerra IC, Cavalcante ANM, Alexandre AV, et al. Procrastination in the early detection of breast cancer. Rev Bras Enferm. 2019;72(Suppl 3):227-34. doi: http://dx.doi.org/10.1590/0034-7167-2018-0547

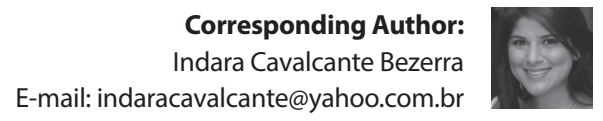

Submission: 07-04-2018 Approval: 05-17-2019

\section{ABSTRACT}

Objective: to analyze the meaning of postponement of breast cancer detection based on interviews with 26 women who were submited to mastectomy. Method: qualitative study based on Symbolic Interactionism with Content Analysis in thematic modality, carried out in a public service outpatient clinic, in a capital city of Northeastern Brazil. Results: faced with the participants' reports, the theme 'meanings attributed to procrastination of breast health care' emerged. The meaning given by women to the reasons for postponing breast care permeate the interfaces between personal reasons and difficulties found in the healthcare network. Final considerations: early detection is considered to be delayed for fear of diagnosis, personal, cultural barriers, and difficulties in health services.

Descriptors: Early Diagnosis; Mastectomy; Breast Neoplasms; Public Health; Qualitative Research.

\section{RESUMO}

Objetivo: analisar o sentido do adiamento da detecção do câncer de mama, a partir de entrevistas com 26 mulheres que foram submetidas à mastectomia. Método: estudo qualitativo e fundamentado no interacionismo simbólico, com Análise de Conteúdo na modalidade temática, realizado em ambulatório de serviço público, numa capital do Nordeste brasileiro. Resultados: ante os relatos das participantes, emergiu a temática 'sentidos atribuídos à procrastinação do cuidado da saúde mamária'. O significado dado pelas mulheres, aos motivos do adiamento do cuidado com a mama, perpassa pelas interfaces entre razões pessoais e dificuldades encontradas na Rede de Atenção à Saúde. Considerações finais: considera-se que a detecção precoce é retardada por medo do diagnóstico, barreiras pessoais, culturais e dificuldades nos serviços de saúde.

Descritores: Diagnóstico Precoce; Mastectomia; Neoplasias da Mama; Saúde Pública; Pesquisa Qualitativa.

\section{RESUMEN}

Objetivo: analizar el sentido del aplazamiento de la detección del cáncer de mama a partir de entrevistas con 26 mujeres que fueron sometidas a la mastectomía. Método: estudio cualitativo fundamentado en el Interaccionismo Simbólico, con Análisis de Contenido en la modalidad temática, realizado en ambulatorio de servicio público, en una capital del nordeste brasileño. Resultados: Ante los relatos de las participantes, emergió la temática 'sentidos atribuidos a la procrastinación del cuidado de la salud mamaria'. El significado dado por las mujeres a los motivos del aplazamiento del cuidado con la mama atraviesan las interfaces entre razones personales y dificultades encontradas en la red de salud. Consideraciones finales: la detección precoz es retardada por miedo al diagnóstico, barreras personales, culturales y dificultades en los servicios de atención a la salud. Descriptores: Diagnostico Temprano; Mastectomía; Neoplasias de la Mama; Salud Pública; Investigación Cualitativa. 


\section{INTRODUCTION}

'Procrastination' comes from the Latin procrastinatus: pro (front) and crastinus (from tomorrow). Refers to action deferral or postponement. Procrastinating can result in stress, guilt, loss of productivity, and shame, compared to other people, for not meeting commitments ${ }^{(1)}$. In this sense, procrastinating a diagnosis or treatment can bring irreparable damage to health.

Breast cancer (CA) is the second most frequent type of tumor among women worldwide, with an incidence of approximately $22 \%$ increased each year. In Brazil, there is an estimate of 59,700 new cases by 2018 , with an estimated risk of 56.33 cases per 100,000 women. The highest rates of incidence and mortality occurred in the South (73.07/100 thousand) and Southeast (69.50/100 thousand), followed by the Center-West (51.96/100 thousand), the Northeast (40.36/100 thousand) and North (19.21/100 thousand). This pathology represents, among women, the main cause of death by $C A^{(2)}$. According to data from the International Agency for Research on Cancer, Globocan (2012), the cumulative risk of a person having and dying from CA in Brazil is respectively $6.3 \%$ and $1.6 \%{ }^{(3)}$.

For Ceará State, the National Cancer Institute estimated the occurrence of 2,200 new cases of breast CA by 2018, highlighting a crude rate of 47.20 cases per 100 thousand women ${ }^{(2)}$. These data place the city of Fortaleza in a prominent position for the programming of actions, regarding early detection (ED), cure, and rehabilitation ${ }^{(2)}$.

Brazilian public policies related to this problem have been developed since the mid-1980s, being driven by the Viva Mulher Program (Programa Viva Mulher) in 1998. Breast CA control is a priority of the country's health agenda and is part of the Strategic Action Plan for Coping with Chronic Noncommunicable Diseases (CNCDs). This plan was launched by the Ministry of Health in 2011, in order to prepare Brazil to confront and detain, in the next ten years, several pathologies, among which is the breast $C^{(4)}$.

In its early stages, breast CA detection can only occur by screening. This promotes a better prognosis of the disease and reduction of mortality, with less radical and more effective treatments, as well as lower morbidity associated with therapy ${ }^{(5-6)}$. Mammography is the gold standard for screening for this neoplasm ${ }^{(7)}$.

When the tumor grows, in some cases, it can be perceived through signs and symptoms, such as a fixed and usually painless nodule; breast skin reddish, retracted or resembling orange peel; changes in the nipple; small nodules in the armpits or in the neck; being able to present externalization of breasts abnormal secretion $^{(8)}$.

If diagnosed in the initial phase, this type of CA presents a great possibility of cure, with low morbidity resulting from the treatment, reducing the suffering of the woman affected by the disease. Nevertheless, late disease diagnosis is still a reality in several regions of Brazil. This can be attributed to the population's difficulty in accessing public health services, the low qualification of professionals involved in cancer care, the inability of the public system to meet the demand or the low capacity of municipal and state managers to define the flow of suspected cases in different care levels ${ }^{(9)}$.

The literature draws attention to the need for greater clarification by the female population about the methods of secondary prevention of breast CA through early diagnosis ${ }^{(9-12)}$. The primary prevention of this problem refers to self-examination, which is always remembered among women ${ }^{(9)}$, probably due to the intense campaigns in the media. Women without adequate knowledge do not have the autonomy to request breast clinical examination during routine visit, as well as mammography, when indicated ${ }^{(10)}$.

A recent study analyzed 168 cases of breast CA regarding care flow and time elapsed between diagnosis and the first treatment. It evidenced an average of 53 days between the diagnosis and the beginning of treatment, which corresponds to the one recommended by Law 12,732 of November 2012, which determines a maximum period of 60 days to start treatment, after definitive diagnosis ${ }^{(13)}$. This finding emphasizes that empowering women about the prevention and ED of breast CA, so that there is no delay in diagnosis, has the most positive results in coping with this pathology.

Given the possibility of early control and breast CA diagnosis, it is important that the woman is guided about prevention, diagnosis, detection, and the need for specific tests, such as Breast Self-Examination (BSE), mammography and, in some cases, ultrasound and magnetic resonance imaging ${ }^{(4)}$.

Diagnostic confirmation usually impacts on social, personal, professional, and affective relationships, and may cause psychological damage in the perception of sexuality, personal image, and self-esteem, in a more striking way than other types of $C \mathrm{~A}^{(14)}$.

People usually constitute images about objects, according to the stimuli suffered, with support in the significant symbols that are attributed to these objects. As the woman expects the best way to live her daily life, in the face of a health problem, she will create mechanisms of resistance and protection, according to what she interprets as a threat ${ }^{(15-16)}$.

In the case of breast CA, the way women have established the symbols and meanings, with support in interaction with other women, health professionals and society in general, may determine that they'silence.'This may condition them not to act at diagnosis, in order not to discover 'patients', characterizing breast health care procrastination ${ }^{(15-16)}$.

Women who underwent mastectomy due to breast CA had their diagnoses or treatments late, which resulted in breast mutilation, in addition to other negative consequences for their life. Through the therapeutic itinerary of these women, traced by their reports, one can know the failures or difficulties that postponed the diagnosis and/or initiation of treatment.

Thus, under the conception of mastectomized women, the aspects that determined the postponement of breast CA ED can elucidate new strategies of care and health promotion. Content would also be subsidized to strengthen actions and policies to cope with this.

In view of the above, the question is: why did women who had a mastectomy did not have breast CA detected early? What is the meaning of breast CA diagnosis procrastination attributed by the mastectomized women?

\section{OBJECTIVE}

To analyze the meaning of breast CA detection procrastination for mastectomized women. 


\section{METHOD}

\section{Ethical aspects}

The study followed the ethical precepts of research involving human beings, with a favorable opinion from the Research Ethics Committee of the Universidade de Fortaleza. Participants signed the Free and Informed Consent Form. To preserve anonymity, women were coded by the word 'Woman', followed by numbers 1 to 26, according to the order in which the interviews were conducted.

\section{Theoretical-methodological framework}

The theoretical-methodological framework used was Symbolic Interactionism. It was understood as a sociological approach with a theoretical perspective that makes possible the understanding of how people interpret objects and interactions with other people with whom they relate. It also enables an understanding of how this process of interpretation leads to individual behavior in specific situations ${ }^{(17-18)}$.

\section{Type of study}

A study with a qualitative approach, based on Symbolic Interactionism (SI), whose meaning of reality is understood as a socially and culturally constituted production ${ }^{(16-17)}$. This process allows access to the subjectivity of the subjects by the expression of their lived experiences before the present reality ${ }^{(17-18)}$.

\section{Methodological procedures}

An individual interview was conducted, without time predefinition, in an interactive and recorded way. Each of the interviews consisted of a two-way conversation (interviewer and patient), with an average duration of 40 minutes. At that time, the sociodemographic profile of participants was identified. Questions were raised about the reasons for breast CA diagnosis procrastination. The interviews were recorded and transcribed in full in order to ensure reports reliability; to facilitate the data organization; and thematic formulation.

The inclusion of new participants was closed by the theoretical saturation of the data, because it is a qualitative research ${ }^{(19)}$.

\section{Study setting and data source}

The study was conducted in December 2015 and January 2016. It was conducted through interviews with 26 mastectomized women, aged 37 to 66 years, served by the Brazilian Unified Health System (SUS - Sistema Único de Saúde); specifically in an outpatient clinic reference in breast CA based in a hospital specialized in Oncology, in the city of Fortaleza, Ceará (CE) State, Brazil.

Women who were included were older than 18 years; submitted to single and/or bilateral mastectomy as a result of breast CA diagnosis for at least six months; without proven metastasis; lived in the area of the $3^{\text {rd }}$ Regional Executive Office of the Health System of Fortaleza; and who were able to interact and communicate for the interview. Participants were identified according to the medical binder records of that service and/or medical records.
Those who came from other municipalities were excluded from the study. In a possible return to the field for clarification, about the interviews, it might be unfeasible to contact them. Women who were under palliative care were excluded.

\section{Collection, organization, and data analysis}

Content Analysis was used in the thematic modality ${ }^{(20)}$, which allowed to overcome the level of common sense and subjectivism in the interpretation, leading to a critical surveillance of the information issued. Minayo ${ }^{(20)}$ states that this technique consists of discovering the nuclei of meaning or themes that make up a communication, which are related to the object of study. There were three stages: 1) pre-analysis: a superficial reading of all the empirical material was carried out, allowing to select the material corpus to be analyzed and to take into account the data representativeness in relation to the object of study; 2 ) material exploration: systematization was carried out by the classification of existing themes in the material. In this phase, the text was reduced to significant words and expressions; and 3) in the last step, the results obtained with the categorical interpretation were treated. At that moment, the analyst proposed inferences and made interpretations, interrelating them with the theory that underlies the object of study. All this process favored to constitute new theoretical and interpretative dimensions, from the analysis of the material.

The information was organized based on significant ideas that sought to answer the guiding questions about breast CA ED procrastination. With this, the following themes emerged from the women's narratives: meanings attributed to breast health care procrastination.

\section{RESULTS}

Most of them were Catholic (92\%), white (53.8\%), and with monthly income below a minimum wage (53.8\%). Half of participants were married and the majority were housewives (38.46\%). As to education, 11 women studied for a period of two to five years, nine claimed to have studied from six to ten years and six of them reported having more than ten years of study.

Regarding the disease diagnosis, four women obtained it under the age of 46 years, which is the difference of the majority of the studies that report being more common breast CA diagnosis between 47 and 56 years ${ }^{(5)}$.

Several reasons were pointed out by the participants for the delay in their breast CA diagnosis, such as fear, denial, difficulty accessing health services, work demands, housework, non-prioritization of self-care, among others.

These were some of the reasons pointed out for procrastinating diagnosis and treatment of breast $C A$, as the speeches show:

[...] I was supposed to be careful a long time ago, but I had to take care of my mother. My mother was 100 years old, there was no one to look after her [...], I had to take care of her so that I could take care of myself. (Woman 1)

[...] / do not have anyone to go with me. Everyone have their things to do. I'm not going to bother them [...]. (Woman 3) 
I went to the doctor, but he prescribed some tests that I left to do later, because I was doing some work at the company I work for [...] I missed the date it was scheduled. I was late to schedule again. Then, when I came back, it was another doctor who asked me to take the exams [...] it was only a few months later. (Woman 4)

Women's reports reinforce fear of diagnosis, surgery, illness, and death:

We're afraid to find it. Search and You Will Find [...]. (Woman 13)

I never liked going to the doctor. We are always afraid. We are ashamed or afraid, I do not know! I know you let it go. (Woman 7)

It's scary, right? I did not want to hear it was cancer. However, it was growing, growing [...], it was cancer! (Woman 13)

I was afraid to operate and have to remove the breast! (Woman 10)

It was really fear of death. I was afraid of dying because of my children. (Woman 13)

I am afraid of that exam they squeeze you [mammography]. (Woman 16)

Because my mom had it and I got scared. What if I had that too? (Woman 13)

I was afraid, right? I've had a family affair and I know how much you suffer. I did not want to know! (Woman 10)

I was going to take the exam the day and only had to go later, because I was afraid to know the results. Then my sister went to pick me up. It took a while for me to go with her, because I thought about going, but I made up that I had something to do that I could not lose. It was excuse, in fact, I was afraid to know. I am trying to improve, but now I'm afraid of this treatment [crying]. Everyone has, right? But that's how it is. (Woman 20)

Self-care postponement is also attributed to the social role of women as caregivers and family centers, as well as the prioritization of other activities to self-care detriment.

I had even noticed a gland in my chest [...], but my mother was a little sick and I had to take care of her. Then I left it for later. Time went by and I did not even notice. (Woman 16)

Since he has difficulty coming, getting here, we let, let [time goes by] [...]. (Woman 3)

The doctor prescribed some exams I left to do later because I was doing some work at the company [...] because I work! Then I left it for later. (Woman 5)

Physical access barriers, vacancy shortages and delayed care in health services are aspects pointed out by the participants:

It took me two months or more, I waited for a vacancy that I did not have. It took long, but they called me. (Woman 1)

[...] sometimes, the doctor does not go [to work] [...], (Woman 3)

[...] it takes a long time. We go one, two times [...]. (Woman 7)
Because it takes too long. You schedule through SUS [...], sometimes it takes too long to score, then we have to pay to take a private exam. (Woman 19)

Because I did prevention every year [...] they [doctors], sometimes they touched my breasts, sometimes they did not play and the last time I did, the doctor did not play [...]. I already have history [of breast CA] in my family. I felt the symptoms and everything. They [health professionals] they saw the severity and they did not help me [...]. The service got stuck! (Woman 2)

Women's lack of knowledge about the disease, symptoms and routine services contributed to postponing breast CA diagnosis:

[...] maybe informing us more, right? Waking us up this concern [...].The woman does not care [for disease prevention], only when it is already big [tumor]. (Woman 24)

[...] we do not know anything; it's being pushed back and forth. No one says anything. Neither how to book the appointment, nor where to take the exam. (Woman 2)

I did not feel anything! It was normal; I did not go for it [...]. Afterwards, I did the mammogram and the doctor also asked for the ultrasound of the breast, was when it appeared [tumor]. (Woman 23)

\section{DISCUSSION}

\section{Meanings attributed to breast health care procrastination}

Health procrastination, depending on its extent, impairs therapeutics and decreases the quality and/or the life time of the client $^{(1,21)}$. Procrastination of care is justified by varied arguments, placing self-care in the background, to the detriment of the social roles women assume in the contemporary world, such as work, children, household chores, family support, always postponing individual care. In this sense, the study showed that individuals usually postpone medical examinations and other health care, linking this behavior to economic factors, lack of information on prevention and detection of diseases, forgetfulness and other priorities $^{(22)}$.

Early disease detection facilitates treatment and improves prognosis $^{(23)}$. In CA, especially breast one, ED is crucial, since postponement may be determinant for the success or otherwise of the treatment ${ }^{(5)}$. Leaving for later, present in the women's discourse of this study, characterizes procrastination, which can compromise various life situations, including health conditions.

Yoshinari et al. ${ }^{(24)}$ study reveals that breast CA is experienced differently by each patient. Contradictory feelings and concepts can coexist, eventually, conflict and become more of a problem to be faced by them. Nevertheless, in this study, there were convergent meanings and meanings about the postponement of breast CA diagnosis among the participants.

Procrastination corresponded to the action of these women, in response to the meaning they attributed to the possibility of 'being sick'. This condition would radically impact on their daily lives and relationships. Delaying the outcome or prognosis can be understood as the denial of a bad possibility for life or even a protective measure for maintaining the leading role in life. 
Postponement, more pointed out by the participants, is related to the culture of fear. CA, even in the present times, is related to a fatal evil, therefore, the ancients avoided mentioning this name in order not to condemn the patient, or even not to attract the disease ${ }^{(15)}$. It was perceptible, in the narratives of the participants of this research, that they did not like to pronounce the word cancer, using other names, such as thing, stuff, bad disease, evil, among others.

Researchers explain that "the stigma of cancer is so strong and in itself so heartwarming of emotions of the most different nuances that, however, much it is quoted with other medical or even scientific names, its expectation of terminality will always be present"(16).

Corroborating these findings, a study in Malaysia ${ }^{(25)}$ highlighted sociocultural barriers that have influenced the postponement of breast health care. Among all, the feeling of fear was the most reported among women. Fear can be understood as "a state of progressive insecurity and anguish, of increasing impotence and disability before the imminent impression that something will happen that the individual wants to avoid, which progressively considers himself less able to do it"(26).

Moreover, according to SI premises ${ }^{(27)}$, people act in relation to things or situations, from the meanings they have for them, which is constructed in the face of interaction and social experience with peers and the environment. These meanings can also take other meanings from an interpretative process that is also based on social relations. For Haguette ${ }^{(28)}$, considering these premises, in the context of health, refers to the importance of understanding the level of knowledge of the population regarding diseases, care, and therapeutic alternatives.

Thus, sickness is felt as a 'twist of fate', signaling the possibility of rupturing the real, causing self-questioning about 'what I do, did and/or could have done with my life.' This reflection can be filled from 'never again', paralyzing, impeding or limiting action, even if momentarily ${ }^{(29)}$.

Indeed, in many contexts and in the face of life's demands, women seek to face the'fear of disease' through procrastination. Often their social, professional and family roles do not want to confirm the signs and symptoms of illness they perceive in their bodies. In addition, for these same reasons, they take second place and are not attentive to health care issues.

Araujo and Fernandes ${ }^{(30)}$ verified in their investigation that the experience of CA, for many women, refers to death, which causes a new meaning of life in the face of uncertainties, insecurities and ignorance of what is to come. From the interactionist perspective, the ways in which women act and understand the disease, are closely related to their life reality, their roles, their level of knowledge about the situation and the support network they live with.

In contemporary times, culture defines women as mothers with families and, as such, is the main reference for "taking care of everything". The fact that society always expects much or everything from the woman causes her to use this subterfuge as a veiled or silent resistance. Thus, the woman postpones the search for help, having the need to resist her body's appeals to her main role as the person responsible for her children, husband, relatives, and friends. With triple working hours, the modern woman responds with subjugation, stating the difficulty of taking time for herself.

It was found in the empirical field studied that the fear of diagnosis still predominates among the major psychological motivations not to seek, in advance, care and ED. In fact, fear permeated all phases experienced by women, prior to diagnosis, in mammography and before the therapeutic course. Experiences experienced by close people also frighten respondents. They revealed knowledge about the predisposition associated with family history.

Before the dread of being with CA, the woman seems to paralyze, is overwhelmed by ambivalent feelings: should I not get diagnosed and follow life or seek to know the truth and launch myself into"itineraries of suffering"? On the other hand, it cannot be categorically stated that fear always means trouble. When they postpone medical examinations and/or general health care, women may be sparing.

The woman takes the time needed to reflect on the meanings of disease detection. She then selects the following steps, examining possible actions to be taken. Finally, she continues her search for the formal health system for confirmation of diagnosis and initiation of therapy. Or she does not come to this last part, pondering that she can walk to an unpredictable future, without control of her and the realization that she is dying ${ }^{(25)}$.

In today's world, women have been the protagonists of managing a wide variety of contexts, being able to deal with various situations involving difficulties, conflicts, time management, and responsibilities. Historically, she has accumulated many roles, without leaving aside the family to the detriment of professional life. The multiplicity of tasks that she fulfills in family and professional life can lead to greater physical and emotional demand ${ }^{(31)}$, which points to the need for greater attention to women's health policies, so that this population do not get sick and take better care of yourself.

The difficulties of access to the service network are recurrent aspects in the interviewees' narratives, which are evidenced as a disincentive for women's participation in preventive visits and routine exams. Indeed, the limitations of public health services reach a large number of people and aggravate the health conditions of the population. Law 12,732/November 12, 2012(32), provides for the treatment of patients with proven malignant neoplasm and establishes a deadline for its initiation, ensuring a maximum of 60 days after the registration of its disease in SUS. Nevertheless, if there is no early diagnosis, this period becomes useless, since the late detection causes the disease to be identified at an advanced stage.

A study carried out in Sergipe ${ }^{(33)}$ showed that women face many barriers in all stages of the trajectory in the search for care for breast CA, which presents a total delay of more than three months. However, the lack of information about the disease and the delay for the scheduling of consultations, examinations and treatment are highlighted, since the waiting list in the public service is quite extensive. The mentioned factors cause the woman to make an arduous pilgrimage that, often, associated with subjective aspects that lead to breast CA detection procrastination.

Moreover, the health team should be prepared to identify the conflicts experienced by the woman after breast CA diagnosis, extending this care to the family, whose support will represent a large part of the resources that she will use in coping with the disease. Since each woman experiences the illness in an intimate and personal way, stiffened, and objective approaches are not appropriate. In fact, a trained team is needed, focusing not only on the patient, but on those who live with it ${ }^{(24)}$.

As stated by Brasil and Silva(34), the SI has a cyclical character, since it associates with comings and goings, meanings, actions, and 
interpretations. Meanwhile, the interaction of women with breast CA with the support network, which includes health professionals, may favor a new meaning for disease, leading to the change of behaviors and attitudes, and the redirection of measures and health care ${ }^{(35)}$.

When analyzing the reality of Brazilian women and the barriers in access to health care in breast CA, a study pointed out that the most delayed specific stage is the first consultation ${ }^{(36)}$. The main factor behind this is the lack of information, in particular, about the resources and routines of the services.

Another motive pointed out by the women, for postponing the diagnosis, was the absence of symptoms. Some women interviewed argued that they did not feel anything and therefore did not need to go to the doctor.

The lack of information about the importance of mammographic screening in the general population leads women to postpone the early diagnosis, which could be performed before any signs or symptoms manifested. According to Gonçalves ${ }^{(33)}$ and Rezende et al. ${ }^{(37)}$, the lack of information about breast CA has, as vague consequences, perceptions about the pathology, which involves its risk factors and the detection of the symptoms. Therefore, nodules, erythemas, and edema are often not valued as they should by women and/or their relatives, which may delay the search for care.

In view of the above, subjective factors such as fear, shame, social roles and other aspects can be observed. They are strongly determined by the culture and meanings derived from women's social relations, making it difficult to search for an early diagnosis. There is a need to make more efforts to raise women's awareness of the importance of breast CA ED, and to strengthen health teams for the management and speed of receiving and caring for this population.

Investing in communication, dissemination, and training of the procedures knowledge adopted in the prevention of breast CA, can help to cope with the disease. To this end, it is necessary to reinforce existing prevention programs and to include information campaigns on the appropriate methods for the prevention of breast CA, stating that only self-examination is not effective in the secondary prevention of this neoplasm ${ }^{(10)}$.

Access to more accurate information empowers women and allows the confrontation of the disease with dignity, if breast CA diagnosis is confirmed. This diagnosis carries with it the potential to disqualify her as a woman, mother, companion, professional, giving her strength and time to stand up to the uncertainty of imminent danger.

\section{Study limitations}

Although it was not the pretense of the research, the collection could have been expanded. This would involve listening to family members and service professionals in order to optimize the understanding of the comprehensive cycle of interaction among these women, which may be considered a limitation of the study.

\section{Contributions to Nursing, Public Policy, and Health}

This study contributes to the area of nursing and public health, by revealing the weaknesses in the process of breast CA ED. It had the potential to subsidize and strengthen new policies, intensify prevention and health promotion actions, and more effectively connect services of the Oncology Care Network (Rede de Atenção Oncológica), impacting the practice of health professionals.

\section{FINAL CONSIDERATIONS}

Throughout the process of illness, women with breast CA suffer significant losses that modify their lives, in broad aspects. Perceiving oneself with breast CA shakes up the routine and makes the person feel anger, denial, fear, sadness, anguish, among other negative symptoms. These subjective emotions associated with extrinsic reasons such as failures in the health network and disinformation promote self-care postponement. In this study, participants revealed that breast CA detection procrastination correlates factors associated with personal and cultural reasons and failures in the interfaces with the public health service, which can lead to serious and sometimes irreversible consequences for breast health and woman's well-being.

Therefore, there should have more assistance in relation to health promotion actions, in order to raise awareness of the population about the importance of breast neoplasm ED, as well as qualification and training of health professionals in cancer care, resulting better prognosis and quality of life for people affected. These strategies promote a reduction in the number of work leave due to diseases, hospitalizations, surgical procedures, chemotherapeutic treatments, medications and deaths from this neoplasm. This has a direct impact on the reduction of public spending on health and on the quality of life of women so dear and indispensable to today's society.

More studies involving other social agents, managers, and professionals should be stimulated in order to emphasize socioeconomic aspects and to involve society in order to reduce as much as possible the damages caused by breast CA.

\section{ACKNOWLEDGMENT}

A special thanks to the women participating in the research for allowing access to their subjectivities in the face of breast cancer.

\section{REFERENCES}

1. Bechara E. Moderna gramática portuguesa. Rio de Janeiro: Lucerna, 2002.

2. Instituto Nacional de Câncer (INCA). Estimativa 2018: Incidência de Câncer no Brasil [Internet]. Rio de Janeiro: INCA; 2018 [cited 2018 June 10]. Available from: https://www.inca.gov.br/publicacoes/livros/estimativa-2018-incidencia-de-cancer-no-brasil

3. Instituto Nacional de Câncer (INCA). Diretrizes para a detecção precoce do câncer de mama no Brasil [Internet]. Rio de Janeiro: INCA; 2015 [cited 2018 Apr 20]. Available from: http://www.inca.gov.br/rbc/n_62/v01/pdf/10-resenha-diretrizes-para-a-deteccao-precoce-do-cancer-de-mama-no-brasil.pdf 
4. Ministério da Saúde (BR). Secretaria de Vigilância em Saúde. Departamento de Análise de Situação de Saúde. Plano de ações estratégicas para o enfrentamento das Doenças Crônicas Não Transmissíveis (DCNT) no Brasil 2011-2022 [Internet]. Brasília: Ministério da Saúde; 2011 [cited 2018 May 20]. Available from: http://bvsms.saude.gov.br/bvs/publicacoes/plano_acoes_enfrent_dcnt_2011.pdf

5. Instituto Nacional de Câncer (INCA). Câncer de mama [Internet]. Rio de Janeiro: INCA; 2017 [cited 2017 Oct 20]. Available from: http:// www2.inca.gov.br/wps/wcm/connect/tiposdecancer/site/home/mama/sintomas

6. Ministério da Saúde (BR). Comissão Nacional de Tecnologias no SUS. Mamografia para o rastreamento do câncer de mama em mulheres com idade abaixo dos 50 anos, entre 50 e 69 anos e com mais de 70 anos. Relatório de Recomendação. Abril, 2015 [Internet]. Brasília: Ministério da Saúde; 2015 [cited 2018 Mar 13]. Available from: http://conitec.gov.br/images/Relatorios/2015/Rastreamento_Mamografia_final.pdf

7. Chetlen, A, Mack J, Chan T. Breast cancer screening controversies: who, when, why, and how? Clin Imaging. 2016;40(2):279-82. doi: 10.1016/j. clinimag.2015.05.017

8. Silva PA, Riul SS. Câncer de mama: fatores de risco e detecção precoce. Rev Bras Enferm. 2011;64(6):1016-21. doi: 10.1590/S0034-71672011000600005

9. Oshiro ML, Bergmann A, Silva RG, Costa KC, Travaim IEB, Silva GB, et al. Câncer de mama avançado como evento sentinela para avaliação do programa de detecção precoce do câncer de mama no Centro-Oeste do Brasil. Rev Bras Cancerol [Internet]. 2014 [cited 2018 Mar 14];60(1):15-23 Available from: https://rbc.inca.gov.br/index2.php

10. Gonçalves CV, Camargo VP, Cagol JM, Miranda B, Mendoza-Sassi RA. Women's knowledge of methods for secondary prevention of breast cancer. Ciênc Saúde Colet. 2017;22(12):4073-82. doi: 10.1590/1413-812320172212.09372016

11. Tejeda S, Darnell JS, Cho YI, Stolley MR, Markossian TW, Calhoun EA. Patient barriers to follow-up care for breast and cervical cancer abnormalities. J Womens Health (Larchmt). 2013;22(6):507-17. doi: 10.1089/jwh.2012.3590

12. Amorim VMSL, Barros MBA, César CLG, Carandina L, Goldbaum M. Fatores associados a não realização da mamografia e do exame clínico das mamas: um estudo de base populacional em Campinas, São Paulo, Brasil. Cad Saúde Pública. 2008;24(11):2623-32. doi: 10.1590/ S0102-311X2008001100017

13. Coelho MF. Assistência terciária aos pacientes com câncer de mama pertencentes à Rede de Atenção Oncológica da $4^{\circ}$ Coordenadoria Regional de Saúde/RS: Estudo Descritivo [Monografia] [Internet]. Rio Grande do Sul: Universidade Federal de Santa Maria; 2018 [cited. Available from: https://repositorio.ufsm.br/handle/1/13270

14. Amorim VMSL, Barros MBA, César CLG, Carandina L, Goldbaum M. Fatores associados a não realização da mamografia e do exame clínico das mamas: um estudo de base populacional em Campinas, São Paulo, Brasil. Cad Saúde Pública. 2008;24(11):2623-32. doi: 10.1590/ S0102-311X2008001100017

15. Tejeda S, Darnell JS, Cho YI, Stolley MR, Markossian TW, Calhoun EA. Patient barriers to follow-up care for breast and cervical cancer abnormalities. J Womens Health (Larchmt). 2013;22(6):507-17. doi: 10.1089/jwh.2012.3590

16. Angerami-Camon VA, Gaspar KC. Psicologia \& Câncer. São Paulo: Casa do Psicólogo; 2013.

17. Blumer H. Symbolic Interctionism perspective and method. California: Prentice-Hall; 1969.

18. Carvalho VD, Borges LO, Rêgo DP. Interacionismo simbólico: origens, pressupostos e contribuições aos estudos em Psicologia Social. Psicol Ciênc Prof. 2010;30(1):146-61. doi: 10.1590/S1414-98932010000100011

19. Martínez-Salgado C. El muestreo en investigación cualitativa: principios básicos y algunas controversias. Ciênc Saúde Colet. 2012;17(3):6139. doi: $10.1590 / \mathrm{S} 1413-81232012000300006$

20. Minayo CS. O desafio do conhecimento: pesquisa qualitativa em saúde. 12a ed. São Paulo: Hucitec; 2010.

21. Ferreira SMA, Panobianco MS, Gozzo TO, Almeida AM. A sexualidade da mulher com câncer de mama: análise da produção científica de enfermagem. Texto Contexto Enferm. 2013;22(3):835-42. doi: 10.1590/S0104-07072013000300033

22. Hamasaki EIM, Kerbauy RR. Será o comportamento de procrastinar um problema de saúde. Rev Bras Ter Comport Cogn [Internet]. 2001 [cited 2017 Dec 06];3(2):35-40. Available from: http://pepsic.bvsalud.org/scielo. php?script=sci_arttext\&pid=S1517-55452001000200005\&lng=pt

23. Gouveia VV, Pessoa VS, Coutinho ML, Barros ICS, Fonseca, AA. Escala de Procrastinação Ativa: evidências de validade fatorial e consistência interna. Psico-USF. 2014;19(2):345-54. doi: 10.1590/1413-82712014019002008

24. Yoshinari STV, Jr GHY, Masson MV, Mello LF. Vivência de mulheres frente ao câncer de mama: revisão da literatura brasileira. Rev Ciênc Saúde. 2017;7(4):20-5. doi: 10.21876/rcsfmit.v7i4.707

25. Norsa'adah B, Rahmah MA, Rampal KG, Knight A. Understanding barriers to Malaysian women with breast cancer seeking help. Asian Pac J Cancer Prev. 2012;13(8):3723-30. doi: 10.7314/apjcp.2012.13.8.3723

26. Dalgalarrondo P. Psicopatologia e semiologia dos transtornos mentais. 2a ed. Porto Alegre: Artmed; 2008.

27. Blumer H. Symbolic interacionism perspectiveand method. Califórnia: Prentice-Hall; 1969.

28. Haguette TMF. Metodologias qualitativas na sociologia. 11 a ed. Petrópolis: Vozes, 2007.

29. Barbosa LNF, Francisco AL, Efken KH. Morte e vida: a dialética humana. Aletheia [Internet]. 2008 [cited 2018 Nov 23];(28):32-44. Available from: http://pepsic.bvsalud.org/scielo.php?script=sci_arttext\&pid=S1413-03942008000200004\&lng=pt

30. Araújo IMA, Fernandes AFC. O significado do diagnóstico do câncer de mama para a mulher. Esc Anna Nery. 2008;12(4):664-71. doi: 10.1590/ S1414-81452008000400009 
31. Andrade LRC, Andrade CAC. O papel da mulher na sociedade contemporânea em divã. In: Seminário Nacional Literatura e Cultura; 2012 maio 3-4. São Cristovão: GELIC/UFS; 2012. p. 1-13.

32. Brasil. Lei no 12.732, de 22 de novembro de 2012. Dispõe sobre o primeiro tratamento de paciente com neoplasia maligna comprovada e estabelece prazo para seu início [Internet]. Diário Oficial da União, 23 nov. 2012. Brasília; 2012 [cited 2017 Oct 20]. Available from: http:// www.planalto.gov.br/ccivil_03/_ato2011-2014/2012/lei/l12732.htm

33. Gonçalves LLC. Trajetória de mulheres com câncer de mama: dos sinais e sintomas ao tratamento [tese]. São Paulo: Universidade de São Paulo; 2013. doi: 10.11606/T.83.2013.tde-22012014-144735

34. Brasil CCP, Silva RM. A voz da professora na integralidade em saúde, v. 1. $1^{\text {a }}$ ed. Fortaleza: Edições UFC; 2016.

35. Lopes CHAF, Jorge MSB. Interacionismo simbólico e a possibilidade para o cuidar interativo em enfermagem. Rev EsC Enferm USP. 2005;39(1):103-8. doi: 10.1590/S0080-62342005000100014

36. Gonçalves LLC, Travassos GL, Almeida AM, Guimarães AMDN, Gois CFL. Barreiras na atenção em saúde ao câncer de mama: percepção de mulheres. Rev Esc Enferm USP. 2014;48(3):394-400. doi: 10.1590/S0080-623420140000300002

37. Rezende MCR, Koch HA, Figueiredo JA, Thuler LCS. Causas do retardo na confirmação diagnóstica de lesões mamárias em mulheres atendidas em um centro de referência do Sistema Único de Saúde no Rio de Janeiro. Rev Bras Ginecol Obstet. 2009;31(2):75-81. doi: $10.1590 /$ S0100-72032009000200005 